\title{
Vegetation and proximity to the river control amorphous silica storage in a riparian wetland (Biebrza National Park, Poland)
}

\author{
E. Struyf ${ }^{1,2}$, W. Opdekamp ${ }^{2}$, H. Backx ${ }^{2}$, S. Jacobs ${ }^{2}$, D. J. Conley ${ }^{1}$, and P. Meire ${ }^{2}$ \\ ${ }^{1}$ Lund University, GeoBiosphere Science Centre, Department of Geology, Sölvegatan 12, 22362 Lund, Sweden \\ ${ }^{2}$ University of Antwerp, Department of Biology, Ecosystem Management Research Group, Universiteitsplein 1c, \\ 2610 Wilrijk, Belgium
}

Received: 17 September 2008 - Published in Biogeosciences Discuss.: 15 January 2009

Revised: 14 April 2009 - Accepted: 16 April 2009 - Published: 23 April 2009

\begin{abstract}
Wetlands can modify and control nutrient fluxes between terrestrial and aquatic ecosystems, yet little is known of their potential as biological buffers and sinks in the biogeochemical silica cycle. We investigated the storage of amorphous silica (ASi) in a central-European riparian wetland. The variation in storage of ASi in the soil of an undisturbed wetland was significantly controlled by two factors: dominance of sedges and grasses and distance to the river (combined $R^{2}=78 \%$ ). Highest ASi storage was found near the river and in sites with a dominance of grasses and sedges, plants which are well known to accumulate ASi. The management practice of mowing reduced the amount of variation attributed to both factors $\left(R^{2}=51 \%\right)$. Although ASi concentrations in soils were low (between 0.1 and $1 \%$ of soil dry weight), ASi controlled the availability of dissolved silica (DSi) in the porewater, and thus potentially the exchange of DSi with the nearby river system through both diffusive and advective fluxes. A depth gradient in ASi concentrations, with lower ASi in the deeper layers, indicates dissolution. Our results show that storage and recycling of ASi in wetland ecosystems can differ significantly on small spatial scales. Human management interferes with the natural control mechanisms. Our study demonstrates that wetlands have the potential to modify the fluxes of both DSi and ASi along the land-ocean continuum and supports the hypothesis that wetlands are important ecosystems in the biogeochemical cycling of silica.
\end{abstract}

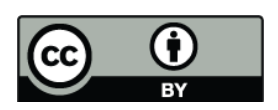

Correspondence to: E. Struyf (eric.struyf@ua.ac.be)

\section{Introduction}

Biologically controlled uptake and storage of silica and its recycling in terrestrial ecosystems is a significant component of the global biogeochemical silica cycle (Conley, 2002). It forms an essential buffer between mineral weathering, the ultimate source of dissolved silica (DSi), and the eventual export to the aquatic environment. Biogenic amorphous silica (ASi) stored in soils as plant phytoliths and diatoms, is several orders of magnitude more soluble than mineral silicates (Farmer et al., 2005) and the recycling of ASi exhibits an important control on terrestrial DSi export (e.g. Derry et al., 2005; Fulweiler et al., 2005; Sommer et al., 2006). DSi mobilization in the terrestrial environment is the primary silica source for aquatic and eventually coastal and oceanic environments (Van Cappellen, 2003), where it is an essential nutrient for diatoms (Bacillarophyceae). The availability of DSi relative to other nutrients can influence the occurrence of harmful algal blooms (e.g. Smayda, 1997). In addition, the uptake of DSi and burial of diatoms on the ocean floor is an important sink for atmospheric carbon on biological time scales (Dugdale et al., 1995). Moreover, terrestrial mineral silicate weathering is an essential controlling mechanism for atmospheric $\mathrm{CO}_{2}$ concentrations on geological timescales (Berner et al., 1983). Understanding the land-based cycling of silica is essential in understanding carbon biogeochemistry and eutrophication.

Yet, the biotic control of land-based silica fluxes is far from understood. Quantifying the ecosystem biotic component is one of the main challenges in understanding the biogeochemical cycling of silica. Research in terrestrial ecosystems has largely focused on forested ecosystems, where phytolith dissolution has been identified as the primary source

Published by Copernicus Publications on behalf of the European Geosciences Union. 
for exported DSi (Bartoli, 1983; Farmer et al., 2005). More recently, a literature overview suggested that wetlands have the potential to exhibit a profound influence on terrestrial silica transport and storage (Struyf and Conley, 2009). Wetlands can modify nutrient fluxes along the aquatic continuum through transformation and storage. Silica rich biomass, together with the frequent occurrence of diatoms and sponges in wetlands, provides the potential for the accumulation of ASi rich soils (Clarke, 2003; Struyf et al., 2005). Struyf and Conley (2009) hypothesized that a trade-off between the storage of ASi in wetland soils and the export of DSi from wetlands depends on hydrological and vegetation characteristics. However, little research has actually focused on the factors controlling accumulation and recycling of $\mathrm{ASi}$ in wetlands that could verify this hypothesis. By contrast, the importance of wetlands in other nutrient cycles ( $\mathrm{N}$ and $\mathrm{P})$ as sinks and processors has been intensively studied (e.g. Gusewell and Koerselman, 2002; Gribsholt et al., 2005), highlighting the role of riparian wetlands in reducing excessive $\mathrm{N}$ and $\mathrm{P}$ inputs to aquatic ecosystems (e.g. Hattermann et al., 2006; Olde-Venterink et al., 2006). Silica cycling related research in wetlands has focused on tidal marshes (Struyf and Conley 2009), which are characterized by low water residence times and frequent flooding leading to the rapid recycling of buried ASi (Struyf et al., 2006), and with increasing sedimentation resulting in more efficient burial of ASi (Struyf et al., 2007a). The marsh grass Phragmites australis is a key participant in the uptake of DSi, its transformation to ASi and recycling in tidal marshes (Struyf et al., 2007b). Research in tidal wetlands clearly shows the importance of hydrological connectivity and vegetation in wetland silica biogeochemistry.

We have examined the storage of $\mathrm{ASi}$ in a centralEuropean riparian wetland in Poland, characterized by a dominance of sedge and grass vegetation. A number of wetland plants are important accumulators of ASi (e.g. Lanning and Eleuterius, 1985; Struyf et al., 2005), but Cyperaceae (sedges) and Poaceae (grasses) are the most efficient accumulators. Wetland grasses and sedges on average contain $0.5-4 \%$ of $\mathrm{Si}$ in their tissues, while exceptionally high values up to $20 \%$ have been recorded (Struyf and Conley, 2009). We sampled for ASi along gradients in distance to the river (as a proxy for hydrology and river connectivity), in the dominance of grasses and sedges and at both managed (annual mowing) and unmanaged sites. Porewater DSi concentrations were sampled as an indicator of recycling of ASi. Our sampling was aimed to test the hypothesis by Struyf and Conley (2009) that silica storage and recycling depends on river connectivity and vegetation. Our data show that river distance and vegetation can explain most of the observed variation in ASi storage, with human management (mowing) interfering with and reducing these control mechanisms.

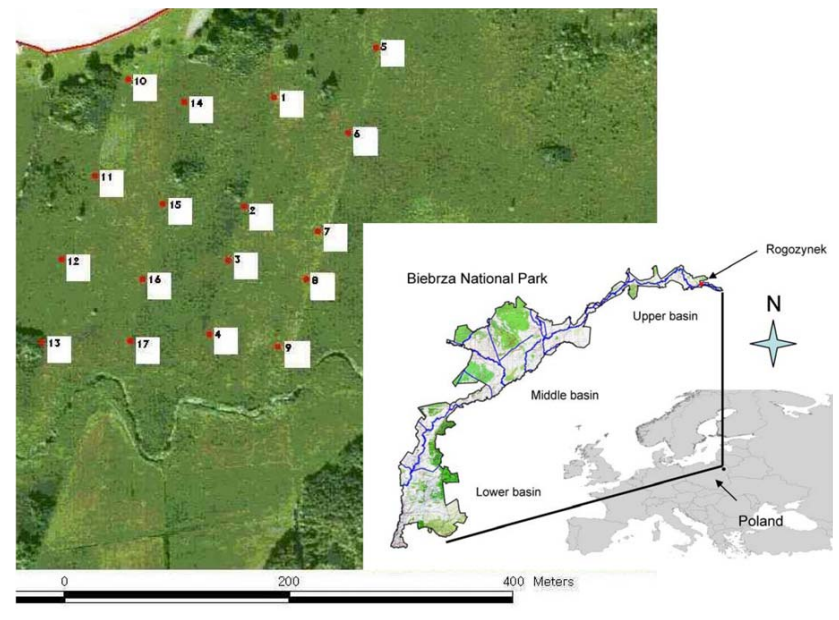

Fig. 1. Biebrza National Park and the position of Rogozynek in the upper basin (right panel). Sampling schedule at Rogozynek (lower panel) with all 17 sampling sites.

\section{Materials and methods}

\subsection{Sampling site}

The Biebrza River valley (Fig. 1), located in NE-Poland $\left(22^{\circ} 30^{\prime}-23^{\circ} 60^{\prime} \mathrm{E}, 53^{\circ} 30^{\prime}-53^{\circ} 75^{\prime} \mathrm{N}\right)$ harbours one of the best preserved wetlands in Central Europe with few draining and land reclamation activities. A regular pattern of marsh and fen communities arranged parallel to the river attests to its pristine character. The river drains a catchment area of ca. $7000 \mathrm{~km}^{2}$. The area has a temperate continental climate with a mean annual gross precipitation of $583 \mathrm{~mm}$ and a mean annual temperature of $6.8^{\circ} \mathrm{C}$. The Biebrza River valley (ca. $900 \mathrm{~km}^{2}$ ) is bordered by moraines and outwash plains and can be divided in three sub-basins, the Lower, Middle and Upper Basin. The relatively narrow Upper Basin (1$3 \mathrm{~km}$ wide) is bordered by an outwash plain in the northwest and delimited by moraines and moraine islands composed of loamy sand and gravel in the south. A detailed description of the Biebrza River valley can be found in Wassen et al. (2006).

Our study site near Rogoynek (Fig. 1) in the Upper Basin consists of several parcels, differing in management practices and vegetation type. Samples for soil ASi and porewater DSi were taken at 17 sampling sites along 4 gradients perpendicular to the Biebrza River channel (Fig. 1) at the end of June 2007. The sampling distance (lowest distance perpendicular to the river) from the river was used in all statistical analysis as a proxy for hydrological connectivity to the river. At each sampling site, both managed and unmanaged vegetation was sampled. The vegetation at unmanaged sites has not been mown for at least 10 years prior to sampling, while managed sites are annually mown. The sites are characterized by gradients in dominance of sedges and grasses (Fig. 4a). A summary of the dominant plant genera (all species with 
Table 1. Dominant vegetation (all genera with higher than 10\% dominance in the plot), distance from the river and grass and sedge dominance $(\mathrm{P}+\mathrm{C}$ dominance, as percentage of the total number of vegetation), summarized for all the sampling spots, as in Figs. 1 and 4.

\begin{tabular}{llll}
\hline & & \multicolumn{2}{c}{ Managed vegetation } \\
\hline Plot & Distance from river (m) & P+C Dominance (\%) & Dominant genera \\
1 & 234 & 83 & Carex (66\%), Festuca (16\%) \\
2 & 150 & 30 & Carex (25\%), Geum (18\%), Filipendula (15\%) \\
3 & 122 & 89 & Carex (82\%) \\
4 & 65 & 54 & Carex (45\%), Menyanthes (10\%) \\
5 & 252 & 60 & Carex (29\%), Festuca (22\%), Ranunculus (18\%) \\
6 & 191 & 80 & Carex (57\%), Festuca 22 (\%) \\
7 & 108 & 61 & Carex (44\%), Geum (13\%), Festuca (9\%) \\
8 & 70 & 61 & Carex (43\%), Festuca (16\%), Filipendula (9\%) \\
9 & 35 & 60 & Carex (58\%), Potentilla (8\%), Menyanthes (8\%) \\
10 & 262 & 44 & Carex (28\%), Festuca (10\%), Ranunculus (9\%) \\
11 & 177 & 42 & Carex (41\%), Ranunculus (14\%), Filipendula (11\%) \\
12 & 105 & 49 & Carex (43\%), Galium (10\%), Ranunculus (10\%) \\
13 & 48 & 35 & Carex (18\%), Ranunculus (15\%), Poa (13\%) \\
14 & 254 & 53 & Carex (41\%), Galium (13\%), Festuca (8\%) \\
15 & 160 & 48 & Carex (29\%), Galium (15\%), Poa (11\%) \\
16 & 90 & 53 & Carex (39\%), Galium (13\%), Poa (10\%) \\
17 & 38 & 41 & Carex (35\%), Galium (14\%), Trifolium (9\%) \\
\hline
\end{tabular}

\begin{tabular}{llll}
\hline & & \multicolumn{2}{c}{ Unmanaged vegetation } \\
\hline Plot & Distance from river (m) & P+C Dominance (\%) & Dominant genera \\
1 & 234 & 78 & Carex (74\%) \\
2 & 150 & 62 & Carex (49\%), Filipendula (16\%) \\
3 & 122 & 67 & Carex (64\%) \\
4 & 65 & 60 & Carex (54\%), Geum (16\%) \\
5 & 252 & 65 & Carex (46\%), Poa (12\%), Equisetum (10\%) \\
6 & 191 & 75 & Carex (56\%), Festuca (19\%) \\
7 & 108 & 56 & Carex (49\%), Galium (8\%) \\
8 & 70 & 64 & Carex (53), Geum (14\%), Festuca (11\%) \\
9 & 35 & 73 & Carex (53\%), Phragmites (14\%), Urtica (13\%) \\
10 & 262 & 57 & Carex (57\%), Viola (15\%), Thelypteris (15\%) \\
11 & 177 & 51 & Carex (42\%), Viola (9\%), Geum (8\%) \\
12 & 105 & 50 & Carex (50\%), Filipendula (17\%) \\
13 & 48 & 43 & Carex (36\%), Geum (23\%), Viola (16\%) \\
14 & 254 & 49 & Carex (49\%), Potentilla (29\%) \\
15 & 160 & 53 & Carex (47\%), Ranunculus (15\%), Potentilla (13\%) \\
16 & 90 & 34 & Carex (33\%), Geum (22\%), Filipendula (13\%) \\
17 & 38 & 37 & Carex (37\%), Geum (17\%), Filipendula (15\%) \\
\hline
\end{tabular}

$10 \%$ or more coverage) at every site is provided in Table 1 , as well as the total grass and sedge dominance. The depth of the groundwater table at different distances from the river sampled from September 2007 to June 2008 is provided in Fig. 2.

\subsection{ASi concentrations}

2 cores $(\varnothing 2 \mathrm{~cm})$ of $30 \mathrm{~cm}$ were taken at every site in June 2007 and in total 68 cores were taken. Every core was subdivided into three sections of $10 \mathrm{~cm}(0-10 \mathrm{~cm}, 10-20 \mathrm{~cm}$ and $20-30 \mathrm{~cm}$ ) and every depth section was analysed for ASi concentration. ASi was determined by alkaline extraction of $30 \mathrm{mg}$ of freeze-dried sediment in $1 \% \mathrm{Na}_{2} \mathrm{CO}_{3}$ solution over a $5 \mathrm{~h}$ period with sub-samples taken at 3,4 and $5 \mathrm{~h}$ and neutralized as adapted by Conley and Schelske (2002). Subsamples were analysed for DSi. DSi-concentrations were plotted against time. The y-intercept was considered to be the ASi content corrected for simultaneous dissolution of (silicate) minerals. 


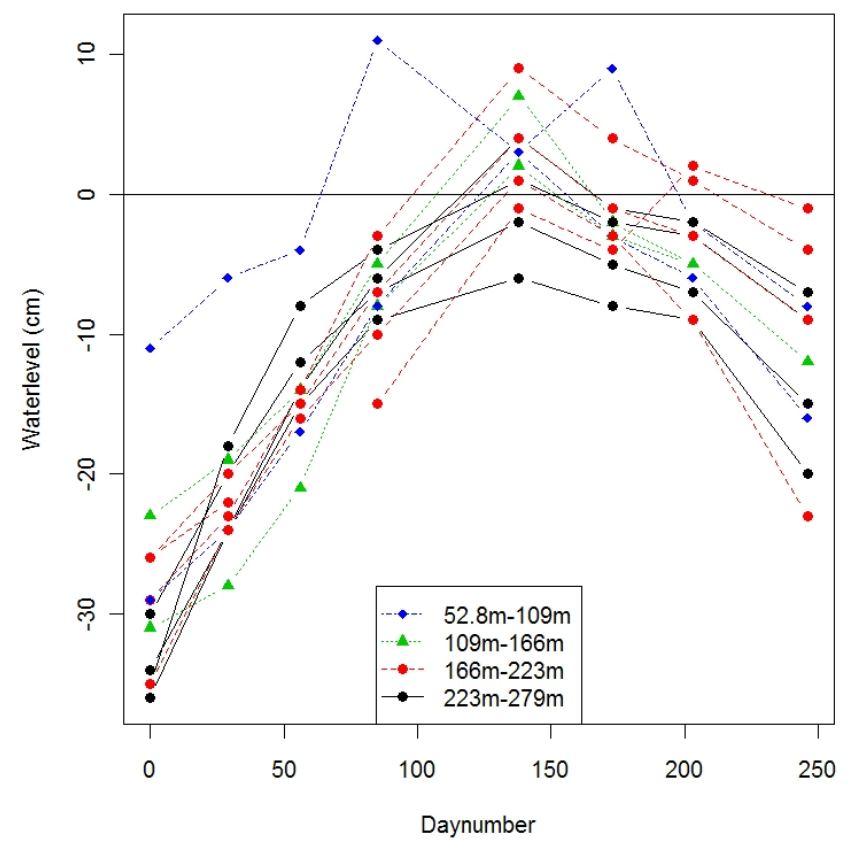

Fig. 2. Groundwater at the Rogozynek site in function of distance from the river, as sampled at 10 locations. The initial day of sampling was 14 september 2007. Positive numbers indicate that groundwater level was above the soil surface.

\subsection{Porewater DSi concentrations}

Porewaters were sampled in the upper $10 \mathrm{~cm}$ using Eijkelkamp polymerous rhizons (diameter $2.5 \times 1.4 \mathrm{~mm}, 10 \mathrm{~cm}$ length) in June 2007. Porewater was sampled at random with 3 rhizons at every site, and the samples were pooled at each site. The pooled sample was analyzed for DSi concentration on an IRIS® ICP (Inductively Coupled Plasma Spectrophotometer, Thermo®).

\subsection{Vegetation}

Vegetation composition at all sampling sites was determined at four randomly chosen plots using a cover pin frame ( 75 points/frame) in June 2006 (Kent and Coker, 1992). The combined cover of grasses (Poaceae) and sedges (Cyperaceae) was expressed as a percentage of total individuals counted, belonging to either of both plant families. Dominance was preferred over number of individuals, as it was assumed to better reflect the overall vegetation composition on a longer time scale, rather than current absolute number of individuals counted. A summary of the dominant plant genera (all species with $10 \%$ or more coverage) at every site is provided in Table 1, as well as the grass and sedge dominance.

\subsection{Statistics}

Extrapolation of $\mathrm{ASi}$, DSi and vegetation structure over the study site was accomplished using the kriging software FIELDS (Nychka, 2007) in the statistical software packet R (R Development Core Team, 2008, http://www.r-project. org/). All other statistical tests were performed using the statistical software package SPSS $®$ 14.0.

\section{Results}

\subsection{ASi concentrations}

The highest ASi concentrations were observed at sites closest to the Biebrza River and, in general, in the top $10 \mathrm{~cm}$ of the soil profile (Fig. 3). However, at sites near the river the highest ASi concentrations were observed in deeper layers. The areal distribution of ASi in the upper $10 \mathrm{~cm}$ of sediment extrapolated over the study area also shows higher ASi concentrations closer to the river (Fig. 4b). General depth related trends in ASi concentration were investigated using paired two-tailed Wilcoxon signed rank tests (corrected for multiple testing), comparing depth sections within the 34 cores taken at sites with unmanaged vegetation and managed vegetation. All depth layers differed significantly for ASi concentration in the unmanaged vegetation $(0-10 \mathrm{~cm}(\mathrm{~L} 1)>10-20 \mathrm{~cm}(\mathrm{~L} 2)>20-30 \mathrm{~cm}$ (L3); L1, L2 $p<0.002$; L1, L3 $p<0.0001$; L2, L3 $p<0.005$ ). Paired Wilcoxon signed rank tests for sites in the managed vegetation indicated that the two deeper layers were not significantly different $(0-10 \mathrm{~cm}(\mathrm{~L} 1)>10-20 \mathrm{~cm}(\mathrm{~L} 2)=20$ $30 \mathrm{~cm}$ (L3); L1, L2 $p<0.0004$; L1, L3 $p<0.002$; L2, L3 $p=0.84$ ). These tests show that the surface layer is significantly enriched in ASi compared to deeper layers.

\subsection{Effect of vegetation and distance from the river}

The relationship between vegetation composition, proximity to the Biebrza River and ASi concentration was analysed for the upper $10 \mathrm{~cm}$ of soil. A significant logarithmic decrease of ASi concentrations in the top $10 \mathrm{~cm}$ of sediment with increasing distance perpendicular to the river was found both at managed $\left(R^{2}=0.29 ; \mathrm{F}_{1,32}=13.36 ; p<0.001\right)$ and unmanaged vegetation sites $\left(R^{2}=0.46 ; \mathrm{F}_{1,32}=27.48 ; p<0.00001\right)$ (Fig. 5a). The relationship showing decreasing ASi concentrations with increasing distance from the river is also clear in Fig. 4b, albeit that the influence of vegetation partly masks the effect. However, there was no clear effect of combined grass and sedge dominance (or grass and sedge dominance separately, data not shown) on observed ASi concentrations in the upper $10 \mathrm{~cm}$ (Fig. 5b). Yet, accounting for the logarithmic river distance effect on ASi concentrations and "correcting" observed ASi concentration with the "expected" ASi concentration from the distance effect, an additional effect of vegetation was found (residual $\mathrm{ASi}=$ observed 
A. Unmanaged vegetation

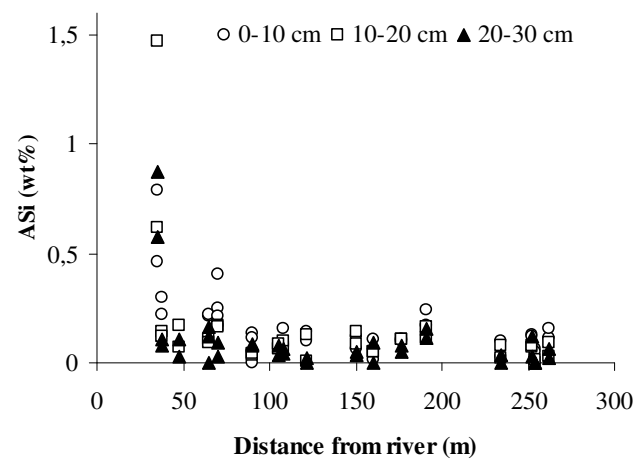

B. Managed vegetation

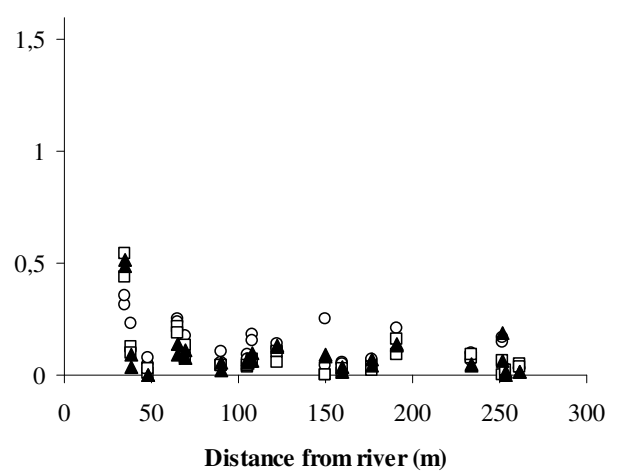

Fig. 3. ASi concentration (\% ASi of sediment weight, wt $\%$ ) in unmanaged (a) and managed (b) vegetation in relation to perpendicular distance from the river to the sampling site, in three different depth layers.
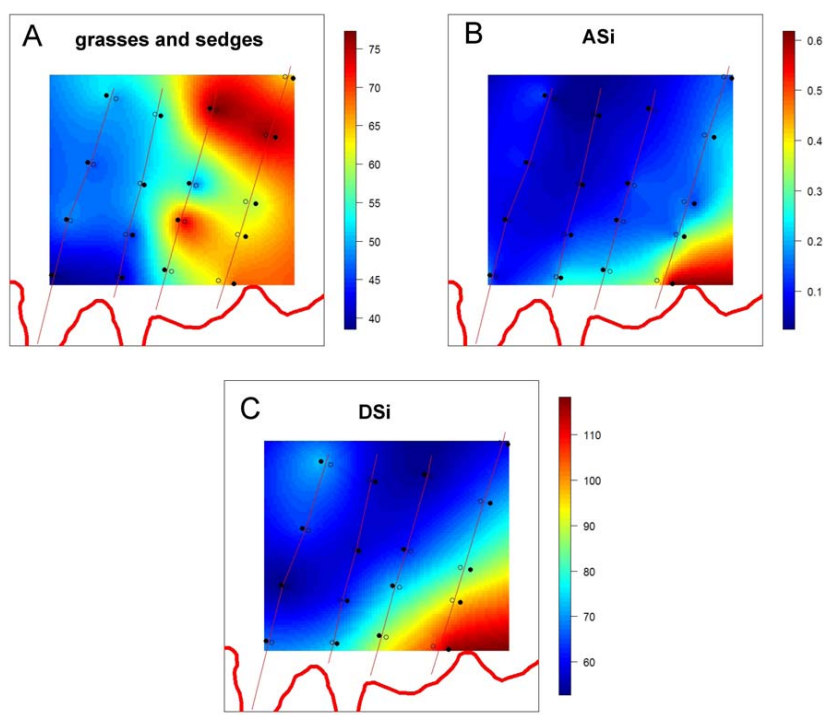

Fig. 4. Grass and sedge dominance (\% of total number of plant individuals, panel a), ASi concentration (\% ASi of sediment weight, wt $\%$, panel b) and porewater DSi ( $\mu \mathrm{m}$, panel c) as observed over the Rogozynek site. Black dots are unmanaged vegetation sampling spots, open white dots managed vegetation. Red straight lines indicate the sampled gradients in distance from the river Biebrza.

ASi - ASi expected from distance). A positive linear relationship between combined Poaceae and Cyperaceae dominance and residual distance corrected ASi is apparent in the top soil (Fig. 5c) in the unmanaged vegetation $\left(R^{2}=0.30\right.$; $\left.\mathrm{F}_{1,32}=14.00 ; p<0.002\right)$. A similar relationship was found in the managed vegetation (Fig. 5c), but the ASi concentration increase with dominance was less steep, and the relationship was only marginally significant $\left(R^{2}=0.13 ; \mathrm{F}_{1,32}=4.78\right.$; $p<0.04)$. It is important to note that there was no significant linear relationship between the distance perpendicular to river and the combined grass and sedge dominance both at managed and unmanaged vegetation sites (Fig. 5d, Managed vegetation: $R^{2}=0.04 ; p>0.46$, Unmanaged vegetation $R^{2}=0.08 ; p>0.28$ ).

Combining the grass and sedge dominance and the distance to the Biebrza River in one factor (by dividing the Poaceae and Cyperaceae dominance by perpendicular distance to the river), a significant linear relationship between this new factor and observed ASi concentration was found, both in the managed and unmanaged vegetation. Combining vegetation and distance to the river we account for $\left(R^{2}\right) 78 \%$ $\left(\mathrm{F}_{1,32}=115.06 ; p<10^{-11}, R^{2}\right.$ for only distance was $\left.46 \%\right)$ of the observed ASi variation at the unmanaged vegetation sites, and $51 \%$ of the variation at the managed vegetation sites $\left(\mathrm{F}_{1,32}=33.41 ; p<0.00001, R^{2}\right.$ for only distance was $\left.29 \%\right)$ (Fig. 6). For both sites containing managed and unmanaged vegetation, the combined factor improves $\mathrm{ASi}$ variation accounted for by 60 and $70 \%$ compared to distance to the river alone. Both the distance from the river and the vegetation independently account for part of the ASi variation observed over the wetland. The combined effect of vegetation and distance is stronger at unmown sites. The combined influence of vegetation and distance from the river is also apparent in Fig. $4 \mathrm{a}$ and $\mathrm{b}$. While the gradient associated with distance from the river is situated along a North-South axis, the grass and sedge dominance primarily increases from West to East. The result is highest ASi concentrations in the SE part and lowest concentrations in the NW part of the Upper Basin.

\subsection{Porewater concentrations}

For both managed and unmanaged vegetations, highest porewater concentrations were generally observed in the sites with highest ASi (Fig. 7). A significant positive linear relationship was actually observed between ASi concentrations (average for both observations in one site and one management type) in the top $10 \mathrm{~cm}$ and pooled porewater DSi concentrations at the same sites for the combined managed and 

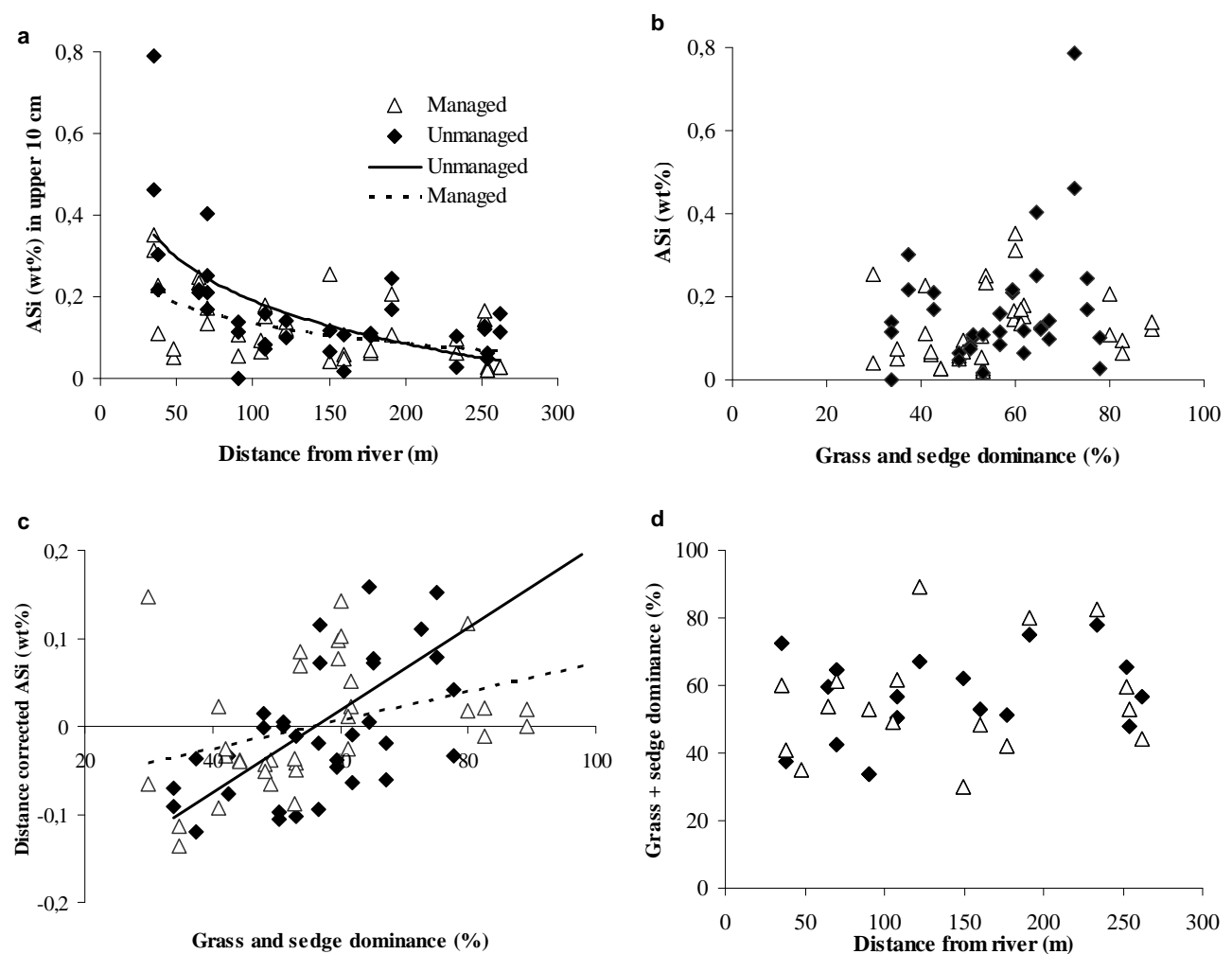

Fig. 5. ASi patterns in both the unmanaged and managed vegetation. (a) ASi in the top $10 \mathrm{~cm}$ of soil vs. distance from the river. (b) ASi in the top $10 \mathrm{~cm}$ of soil vs. grass and sedge dominance in vegetation. (c) distance effect "corrected" ASi in top $10 \mathrm{~cm}$ of soil vs. grass and sedge dominance. (d) distance from the river and grass and sedge dominance as independent variables.

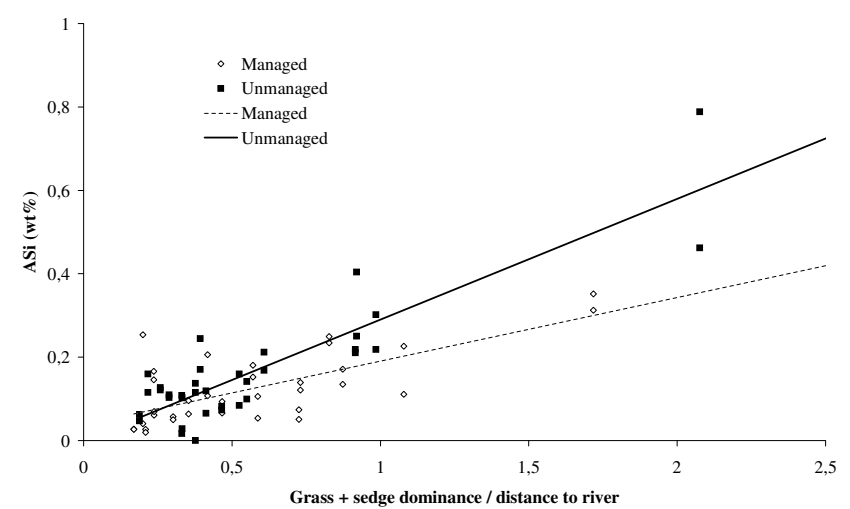

Fig. 6. Relation between a factor combining vegetation and distance (vegetation dominance (\%) divided by distance from the river $(\mathrm{m})$ ) and the distribution of ASi concentration in the top $10 \mathrm{~cm}$ of soil in the unmanaged and managed vegetation.

unmanaged datasets $\left(R^{2}=0.45 ; \mathrm{F}_{1,32}=12.04 ; p<0.001\right)$. The association between soil ASi and porewater DSi is evident in Fig. $4 \mathrm{~b}$ and c, where porewater DSi shows the same gradient as ASi concentrations.

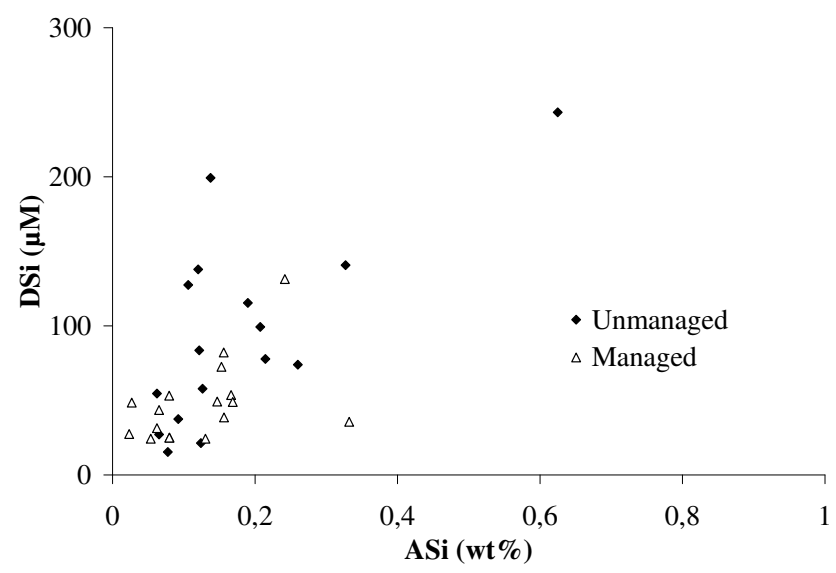

Fig. 7. ASi in soil (averaged per two observations in the same site and the same management type) vs. observed porewater DSi concentrations. Observations are for both managed and unmanaged vegetation.

\section{Discussion}

We show here that the storage of ASi in riparian wetlands is significantly related to riverine connectivity and vegetation, 
as previously hypothesized by Struyf and Conley (2009). In this review, the authors showed that wetlands can profoundly impact the biogeochemical silica cycle through the activities of silica accumulating organisms such as diatoms, sponges, grasses and sedges, although few studies have documented this role of wetlands in silica cycling. Our data support this new understanding. In addition, we show that ASi storage in wetlands is highly variable on small spatial scales, and that recycling to DSi is directly affected by this variation. Our data suggest a link between vegetation (dominance of grasses and sedges) and ASi storage. Evidence linking vegetation to storage of ASi in soils has been available from other ecosystems. In forest soils, higher ASi concentrations in soil profiles occur in forests dominated by beech (relatively rich in $\mathrm{ASi}$ ) as compared to pine, a species poor in $\mathrm{Si}$ (Bartoli and Souchier, 1978; Bartoli, 1983; Saccone et al., 2008). The largest accumulation of ASi in soils has been observed at the island of Réunion from the historical accumulation of phytoliths contained in bamboo, the most efficient $\mathrm{Si}$ accumulator among all higher plants (Meunier et al., 1999). Blecker et al. (2006) hypothesized that storage of ASi in grasslands also strongly depends on precipitation, with high precipitation and frequent soil water renewal stimulating export of DSi from the system, after dissolution of soil ASi.

\subsection{The river distance proxy}

In our study, river distance has been used as a proxy for hydrological characteristics and river connectivity. The proxy accounted for a significant fraction of the variation in $\mathrm{ASi}$ concentrations, independently from grass and sedge dominance. We hypothesize that the observed variation of $\mathrm{ASi}$ with distance from the river can be explained by a mechanism observed previously in tidal wetlands. During winter and spring, the Biebrza River floods the Rogozynek site. During these flooding events, the river imports suspended material into the floodplain, potentially co-importing ASi as both phytoliths and diatom frustules in suspended particulate matter. Within the wetland, stream velocities quickly drop, causing all but the lightest particles to be deposited near the river. In tidal marshes, it has been shown that most suspended matter is deposited close to the river or creek banks (Temmerman et al., 2003), and a similar process was observed in non-tidal floodplains (Asselman and Middelkoop, 1995). Dense vegetation, as observed along the Biebrza, further stimulates rapid settling of particulate suspended matter. The highest import of allochtonous ASi is therefore expected near the river. Another possible mechanism for the enhanced ASi concentrations near the river, would be a tendency for more Si rich grasses and/or sedges to occur. The site richest in ASi (site 9) was characterized by a relatively important dominance of Phragmites australis, well known for its large content of ASi compared to most other grasses (Hodson et al., 2002; Struyf et al., 2005). Unfortunately, we have no data of ASi in aboveground biomass for the Rogozynek site.
Storage of ASi could also be directly related to groundwater hydrology. Frequent oxidation-reduction cycles have been proposed to stimulate the dissolution of ASi (Beckwith and Reeve, 1963; Sommer et al., 2006) with the sorption of DSi into sesquioxides under oxygenated conditions and adsorbed DSi subsequently released after a return to reduced conditions with dissolution of iron oxides. We have no full hydrological characterization of the site, and cannot confirm if oxidation-reduction is more intense at sites farther from the river. However, at least one piezometer near to the river showed persistent reduced conditions. Permanent water-logging could also slow dissolution of ASi for long time-periods through the build-up of DSi concentrations in the soil water. At sites with more frequent flooding and flushing of porewater with a greater flow of water, enhanced dissolution would be expected. Finally, more permanent wet conditions could enhance the growth of diatoms and sponges enhancing the accumulation of ASi. It is clear that the link between ASi storage and recycling in wetlands and hydrology needs further study to quantify its impact on the smallscale variation observed.

\subsection{Vegetation and management}

Our results demonstrate that the pre-dominance of ASi rich vegetation can significantly stimulate ASi storage in wetland soils, as previously shown on larger spatial scales in different ecosystems (e.g. Bartoli, 1983; Jensen et al., 2003). This would imply that Poaceae and Cyperaceae dominance, as frequently observed in wetlands, increases DSi availability in soils available to plants by building a recyclable pool of soil ASi. Increased DSi availability through dissolution of ASi could in turn enhance grasses' and sedges' competitiveness. DSi uptake by plants is well known to enhance their resistance to multiple stressors, and thus potentially their competitiveness (e.g. Epstein, 1999; Massey et al., 2007). We hypothesize that ASi build-up as a result of biomass burial, and resulting high porewater DSi concentrations, might reinforce DSi availability and grasses' dominant position, resulting in a positive feedback loop. A continuous import of DSi from the river or from groundwater is a necessary condition for this hypothesis of surficial ASi build-up and should be fulfilled in a majority of riparian wetland sites, buffering groundwater and surface water fluxes between terrestrial and aquatic environments.

Riverine connectivity and vegetation accounted for more of the observed variation in ASi concentrations at sites not managed by mowing. This is coherent with increased trapping of allochtonous material in dense tussock vegetation and increased grass biomass burial in the absence of mowing. The ASi concentrations in our study site were low $(<1 \%$ by weight), yet control of ASi on DSi concentrations was apparent. ASi is well-known for the control it exhibits on soil DSi concentrations (Farmer et al., 2005; Struyf et al., 2005), as it is more soluble than mineral silicates (Van Cappellen 2003). 
The depth gradient of preservation we observed also indicates dissolution of ASi with depth. The results imply that wetland management and its impact on ASi storage in wetlands, can consequently alter DSi available in the soil water. Export of water from the wetland to the aquatic environment mainly occurs as advective leakage to the river of soil water, especially during rain events, or through vertical leakage to the groundwater. As such, ASi dissolution probably controls export of DSi from the riparian habitat into the river system. In estuaries, wetlands are buffers in the silica cycle, exporting $\mathrm{Si}$ after recycling of buried $\mathrm{ASi}$ in times of Si-depletion (Struyf et al., 2006; Jacobs et al., 2008). Porewater DSi is the main source for the DSi export (Struyf et al., 2006). We suggest that a similar mechanism occurs in non-tidal wetlands.

\section{Conclusions}

An increasing number of studies now indicate that wetlands can form both sinks and sources for $\mathrm{Si}$ in river ecosystems (Struyf and Conley 2009). Our results show that relatively large variation in wetland ASi storage can occur on local, small spatial scales. We provide the first experimental evidence that distance from the river and vegetation can significantly influence ASi dynamics within wetlands over small spatial scales. The relative importance of local hydrology vs. allochtonous import of material could not be distinguished in this study, as distance from the river could be directly linked to both (although the presented data suggest that groundwater hydrology is rather uniform over the whole site). Future work should further constrain and identify these factors. Our understanding of the importance of wetlands to riverine Si biogeochemistry and the transport of Si along the land-ocean continuum is growing. To improve our understanding of both the sink and source functions, exchange studies in a variety of wetlands are a necessary prerequisite, as well as enhanced understanding of wetland Si dynamics. Our results indicate that vegetation and hydrology should be included as forcing factors in these studies. The importance of riverine $\mathrm{Si}$ transport in coastal productivity, where $\mathrm{Si}, \mathrm{N}$ and $\mathrm{P}$ exhibit important controls on phytoplankton composition and productivity, certainly warrants a scientific effort that would enable our understanding of Si biogeochemistry to increase to the level of understanding achieved for $\mathrm{N}$ and $\mathrm{P}$ cycling.

Acknowledgements. Eric Struyf and Daniel Conley acknowledge EU Marie Curie Actions (SWAMP MEIF-CT-2006-040534, COMPACT MEXC-CT-2006-042718) for funding. Wout Opdekamp and Eric Struyf acknowledge FWO (Flemish Research Foundation) for funding their respective Ph.D. and postdoc grants. We would further like to acknowledge Crafoord foundation (Sweden) for funding our research. Fiona Franken was a great help during the vegetation mapping. We would like to thank all referees who commented on the manuscript.

Edited by: P. Van Cappellen

\section{References}

Asselman, N. E. M. and Middelkoop, H.: Floodplain Sedimentation - Quantities, Patterns and Processes, Earth Surf. Proc. Land, 20, 481-499, 1995.

Bartoli, F. and Souchier, B.: Cycle et rôle du silicium d'origine végétable dans les écosystèmes forestiers tempérés, Ann Sci For 35, 187-202, 1978.

Bartoli F.: The biogeochemical cycle of silicon in two temperate forest ecosystems. Ecol. Bull., 35, 469-476, 1983.

Beckwith, R. S. and Reeve, R.: Studies on soluble silica in soils. The sorption of silicic acid by soils and minerals, Aust. J. Soil. Res., 1, 157-168, 1963.

Berner, R. A., Lasaga, A. C., and Garrels, R. M.: The carbonatesilicate geochemical cycle and its effect on atmospheric carbon dioxide over the past 100 million years, Am. J. Sci., 283, 641683, 1983.

Blecker, S. W., McCulley, R. L., Chadwick, O. A., and Kelly, E. F.: Biologic cycling of silica across a grassland bioclimosequence. Global Biogeochem Cycles, 20, GB3023, doi:10.1029/2006GB002690, 2006.

Clarke J.: The occurrence and significance of biogenic opal in the regolith. Earth Sci Rev, 60, 175-194, 2003.

Conley, D. J. and Schelske, C. L.: Biogenic silica, in: Tracking Environmental Change Using Lake Sediments: Biological Methods and Indicators, Smol, edited by: J. P., Birks, H. J. B., and Last, W. M., Kluwer Academic Press, 281-293, 2001.

Conley, D. J.: Terrestrial ecosystems and the global biogeochemical silica cycle, Global Biogeochem Cy., 16, GB1121, doi:10.1029/2002GB001894, 2002.

Derry, L. A., Kurtz, A. C., Ziegler, K., and Chadwick, O. A.: Biological control of terrestrial silica cycling and export fluxes to watersheds, Nature, 433, 728-731, 2005.

Dugdale, R. C., Wilkerson, F. P., and Minas, H. J.: The role of a silicate pump in driving new production, Deep-Sea Res. Pt. I, 42, 697-719, 1995.

Epstein, E.: Silicon, Annual Rev. Plant Phys., 50, 641-664, 1999.

Farmer, V. C., Delbos, E., and Miller, J. D.: The role of phytolith formation and dissolution in controlling concentrations of silica in soil solutions and streams, Geoderma, 127, 71-79, 2005.

Fulweiler R. W. and Nixon, S.: Terrestrial vegetation and the seasonal cycle of dissolved silica in a southern New England coastal river, Biogeochemistry, 74, 115-130, 2005.

Gribsholt, B., Boschker, H. T. S, Struyf, E., Andersson, M., Tramper, A., De Brabandere, L., Van Damme, S., Brion, N., Meire, P., Dehairs, F., Middelburg, J. J. and Heip, C.: Nitrogen processing in a tidal freshwater marsh: a whole ecosystem $15 \mathrm{~N}$ labeling study. Limnol Oceanogr, 50(6), 1945-1959, 2005

Gusewell, S. and Koerselman, M.: Variation in nitrogen and phosphorus concentrations of wetland plants, Perspect Plant. Ecol., 5, 37-61, 2002.

Hattermann, F. F., Krysanova, V., Habeck, A., and Bronstert, A.: Integrating wetlands and riparian zones in river basin modelling. Ecol. Model., 199, 379-392, 2006.

Hodson, M. J., White, P. J., Mead, A., and Broadley, M. R.: Phylogenetic variation in the silicon composition of plants, Ann. Bot.London, 96, 1027-1046, 2005.

Jacobs, S., Struyf, E., Maris, T., and Meire, P.: Spatio-temporal aspects of silica buffering in restored tidal marshes, Est. Coast Shelf Sci., in press, 2008. 
Jensen, J. E., Cooper, S. R., and Richardson, C. J. : Calibration of modern pollen along a nutrient gradient in Everglades Water Conservation Area-2A, Wetlands, 19, 675-688, 1999.

Kent, M. and Coker, P.: Vegetation Description and Analysis: a practical approach, Chichester, John Wiley \& Sons Ltd, 363 pp., 1992.

Lanning, F. C. and Eleuterius, L. N.: Silica and ash in tissues of some plants growing in the coastal area of Mississippi, USA, Ann. Bot.-London, 56, 157-172, 1983.

Massey, F. P., Ennos, A. R., and Hartley, S. E.: Grasses and the resource availability hypothesis: the importance of silica-based defences, J. Ecol., 95, 414-424, 2007

Meunier, J.-D.: Biogenic silica storage in soils. Geology, 27, 835838, 1999.

Nychka, D.: FIELDS: Tools for spatial data, R package version 4.1, 2007.

Olde Venterink, H., Vermaat, J. E., Pronk, M., Wiegman, F., van der Lee, G. E. M., van den Hoorn, M. W., Higler, L., and Verhoeven, J. T. A.: Importance of sediment deposition and denitrification for nutrient retention in floodplain wetlands, Appl. Veg. Sci., 9, 163-174, 2006

R Development Core Team: R: A language and environment for statistical computing, R Foundation for Statistical Computing, Vienna, Austria, http://www.R-project.org, 2008.

Smayda, T. J.: Harmful algal blooms: Their ecophysiology and general relevance to phytoplankton blooms in the sea. Limnol Oceanogr, 42, 1137-1153, 1997.

Sommer, M., Kaczorek, D., Kuzyakov, Y., and Breuer, J.: Silicon pools and fluxes in soils and landscapes - a review (169, 310 pp., 2005), J. Plant. Nutr. Soil Sci., 169, 582-582, 2006.
Struyf, E., Van Damme, S., Gribsholt, B., Middelburg, J. J., and Meire, P.: Biogenic silica in freshwater marsh sediments and vegetation, Mar. Ecol. Prog. Ser., 303, 51-60, 2005

Struyf, E., Dausse, A., Van Damme, S., Bal, K., Gribsholt, B., Boschker, H. T. S., Middelburg, J. J., and Meire, P.: Tidal marshes and biogenic silica recycling at the land-sea interface, Limnol. Oceanogr., 51(2), 838-846, 2006.

Struyf, E., Temmerman, S., and Meire, P.: Dynamics of biogenic $\mathrm{Si}$ in freshwater tidal marshes: $\mathrm{Si}$ regeneration and retention in marsh sediments (Scheldt estuary), Biogeochemistry, 82, 41-53, 2007a.

Struyf E., Van Damme S., Gribsholt B., Bal K., Beauchard O., Middelburg J. J. and Meire P.: Phragmites australis and Si cycling in tidal wetlands, Aquat. Bot., 87, 134-140, 2007b.

Struyf, E. and Conley, D. J.: Silica, an essential nutrient in wetland biogeochemistry, Front. Ecol. Environ., 7(2), 88-94, 2009.

Temmerman, S., Govers, G., Wartel, S., and Meire P.: Spatial and temporal factors controlling short-term sedimentation in a salt and freshwateter tidal marsh, Scheldt estuary, Belgium, SouthWest Netherlands, Earth Surf. Proc. Land, 28, 739-755, 2003.

Van Cappellen, P.: Biomineralization and global biogeochemical cycles, Rev. Mineral Geochem., 54, 357-381, 2003.

Wassen, M. J., Okruszko, T., Kardel, I., Chormanski, J., Swiatek, D., Mioduszewski, W., Bleuten, W., Querner, E. P., El Kahloun, M., Batelaan, O., and Meire, P.: Eco-Hydrological Functioning of the Biebrza Wetlands: Lessons for the Conservation and Restoration of Deteriorated Wetlands, in: Wetlands: Functioning, biodiversity conservation and restoration, edited by: Bobbink, R., Beltman, B., Verhoeven, J. T. A., and Whigham, D. F., Ecological studies, 191, 285-310, 2006. 